\title{
Haemoglobin Lepore Boston and elliptocytosis in a family of Indonesian-German ancestry
}

\author{
L. N. WENT, W. W. de JONG,* and S. E. BOS \\ Department of Human Genetics, Faculty of Medicine and Elisabeth Hospital, Leiden, The Netherlands
}

\begin{abstract}
Summary. A family is presented in which $\mathrm{Hb}$ Lepore Boston was found in six individuals over three generations. The gene must have had its origin either in Java (Indonesia) or in what is now the Federal Republic of Germany. The haemoglobin was characterized by amino-acid analysis of the six tryptic peptides that have a different composition in the $\beta$ - and the $\delta$-chain. The ratio of glycine to alanine in position 136 of the fetal haemoglobin, which was somewhat raised in the Hb Lepore carriers, averaged $31: 69$.

In addition an elliptocytosis gene was found, which was inherited independently from $\mathrm{Hb}$ Lepore; the simultaneous presence of elliptocytosis in three family members did not seem to aggravate the mild anaemia caused by $\mathrm{Hb}$ Lepore.
\end{abstract}

The Lepore haemoglobins are interesting from a molecular-, clinical-, and population-genetical point of view. Structurally they are characterized by the presence of globin chains which are fusion products of $\delta$ - and $\beta$-chains. These $\delta \beta$-chains seem to be the result of unequal crossing-over between the closely linked $\delta$ - and $\beta$-genes (Baglioni, 1962). Three different types of $\mathrm{Hb}$ Lepore are known, which differ in the position of the crossing-over. The regions of $\delta \beta$ fusion in $\mathrm{Hb}$ Lepore Hollandia, $\mathrm{Hb}$ Lepore Baltimore, and $\mathrm{Hb}$ Lepore Boston are located between residues 22 and 50,50 and 86 , and 87 and 116, respectively. Hb Lepore Hollandia is rather common among the Papuans of New Guinea (Barnabas and Muller, 1962). Hb Lepore Baltimore has been characterized once in a North American negro (Ostertag and Smith, 1969). Hb Lepore Boston is rather wide spread in middle- and eastern-Mediterranean populations (Fessas, Stamatoyannoupoulos, and Karaklis, 1962; Quattrin, 1967; Duma et al, 1968) and is also present in Jamaican negroes (Ahern et al, 1972). Definite biochemical characterization of the $\delta \beta$-chain of $\mathrm{Hb}$ Lepore Boston has only been performed in some individuals of Italian ancestry (Baglioni, 1965; Labie,

\footnotetext{
Received 9 April 1974.

* Present address: Department of Biochemistry, Faculty of Science, Nijmegen, The Netherlands.
}

Schroeder, and Huisman, 1966; Baglioni and Ventruto, 1968), in three Jamaican negro families (de Jong, 1969; Ahern et al, 1972), in two Macedonians (L. F. Bernini, personal communication), and in a case from Greece (Baglioni and Ventruto, 1968). We now report the finding and characterization of $\mathrm{Hb}$ Lepore Boston in a Dutch family of Indonesian and German ancestry. This family possessed in addition a gene for hereditary elliptocytosis, which provided the opportunity to study the interaction between $\mathrm{Hb}$ Lepore and elliptocytosis.

\section{Methods}

Haematological data were obtained using standard methods. Starch gel electrophoresis of haemolysates was carried out in Tris-EDTA-borate buffer, $\mathrm{pH} 8.9$ (Smithies, 1965). Fetal haemoglobin was estimated using the alkali-denaturation procedure of Singer, Chernoff, and Singer (1951). Quantitation of Hb Lepore and $\mathrm{Hb} \mathrm{A}_{2}$ was done on DEAE-cellulose columns according to the method of Bernini (1969). The methods for the structural characterization of $\mathrm{Hb}$ Lepore were the same as described previously (de Jong, Bernini, and Khan, 1971) and comprised the isolation of pure $\mathrm{Hb}$ Lepore, conversion to globin, separation of $\alpha$ - and $\delta \beta$-chains, aminoethylation and tryptic digestion, peptide mapping, and amino-acid analyses of tryptic peptides.

The proportions of the two types of $\gamma$-chains, ${ }^{A} \gamma$ and ${ }^{\mathrm{G}} \gamma$ were determined in the fetal haemoglobin present in 
the carriers of $\mathrm{Hb}$ Lepore by amino-acid analysis of the C-terminal cyanogen bromide fragment of the $\gamma$-chains (de Jong, 1971).

\section{Results}

The index case (III.7, Fig. 1) was first seen at the age of 7 because of a fever of unknown but possibly viral origin. On physical and laboratory examination the only abnormality was a mild anaemia. After recovery from the fever the mild anaemia persisted (iron was administered without success) and was analysed in greater detail. This analysis showed: $\mathrm{Hb} 10.5 \mathrm{~g} / 100 \mathrm{ml}$., haematocrit $36 \%$, red cells $4.4 \times 10^{6} / \mu 1$., white cells $2300 / \mu 1$. with normal differential count, platelets $150 \cdot 000 / \mu 1$., sedimentation rate $2 \mathrm{~mm} /$ hour, total bilirubin $0.6 \mathrm{mg} / 100 \mathrm{ml}$. (conjugated $0.1 \mathrm{mg} / 100 \mathrm{ml}$.), free serum iron 178 $\mu \mathrm{g} / 100 \mathrm{ml}$., latent iron binding capacity $158 \mu \mathrm{g} / 100$ $\mathrm{ml}$. (saturation 53\%). The morphology of the red cells was reported abnormal with anisocytosis and some basophil stippling. The direct Coombs test was negative. The osmotic resistance of the red cells was slightly increased. The bone marrow was somewhat hypoplastic with a mild iron deficiency. The examination of the urine gave normal results.

Following the finding of an abnormal haemoglobin, migrating in the position of $\mathrm{HbS}$, more detailed studies were performed on the blood of the
I

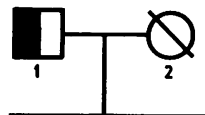

II

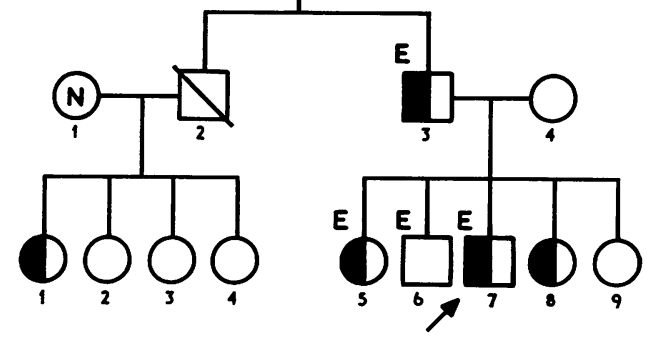

$\square \mathbf{D}$

(N)

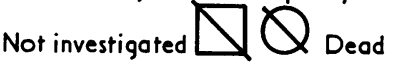

Fig. 1. Family pedigree.

index case and of his living family members. The same abnormal haemoglobin was found in a further five family members in an amount of around 9-10\% of all haemoglobin. The family history revealed that III.5 had as a young girl been chronically anaemic, while the father (II.3) when younger had frequently had iron supplementation. The deceased mother (I.2) of the father was Indonesian. The mother of the grandfather, I.1, was likewise

TABLE

FINDINGS OF THE HAEMATOLOGICAL STUDIES, THE HAEMOGLOBI

\begin{tabular}{|c|c|c|c|c|c|c|c|c|c|c|}
\hline $\begin{array}{l}\text { Pedigree } \\
\text { Number }\end{array}$ & Sex & $\begin{array}{c}\text { Year } \\
\text { of } \\
\text { Birth }\end{array}$ & $\underset{(\mathrm{g} / 100 \mathrm{ml} .)}{\mathrm{Hb}}$ & $\underset{(\%)}{\mathbf{H t}}$ & $\begin{array}{l}\text { Red Cells } \\
\left(\times 10^{6} / \mu 1 .\right)\end{array}$ & $\underset{\left(\mu^{3}\right)}{\operatorname{MCV}}$ & МСНС & $\begin{array}{c}\text { Reticulo- } \\
\text { cytes } \\
(\%)\end{array}$ & $\underset{(\%)}{\mathbf{H b}} \mathbf{F}$ & $\mathrm{G} \gamma: \mathbf{A} \gamma$ \\
\hline 1.1 & $\mathbf{M}$ & 1884 & $\begin{array}{l}15 \cdot 4 \\
14.9 \\
\end{array}$ & $\begin{array}{l}46 \cdot 8 \\
47 \cdot 5 \\
\end{array}$ & $6 \cdot 13$ & 77 & $\begin{array}{l}33.5 \\
31.5 \\
\end{array}$ & $\begin{array}{l}1 \cdot 7 \\
1 \cdot 7 \\
\end{array}$ & $\begin{array}{l}3 \cdot 5 \\
2 \cdot 6 \\
\end{array}$ & $39: 61$ \\
\hline II. 3 & $\mathbf{M}$ & 1923 & $13 \cdot 7$ & $40 \cdot 8$ & $6 \cdot 32$ & 65 & $34 \cdot 0$ & 0.6 & 1.5 & $28: 72$ \\
\hline II.4 & $\mathbf{F}$ & 1930 & $13 \cdot 2$ & $39 \cdot 0$ & 3.98 & 98 & 33.0 & $1 \cdot 0$ & 0.7 & \\
\hline III.1 & $\mathbf{F}$ & 1950 & $12 \cdot 9$ & $38 \cdot 7$ & 5.53 & 70 & 34.0 & $2 \cdot 9$ & $2 \cdot 8$ & $23: 77$ \\
\hline III. 2 & $F$ & 1951 & $12 \cdot 7$ & $38 \cdot 7$ & $4 \cdot 37$ & 89 & 33.5 & nd & 0.8 & \\
\hline III. 3 & $\mathbf{F}$ & 1954 & $14 \cdot 1$ & $42 \cdot 7$ & 4.60 & 93 & 33.5 & nd & 0.6 & \\
\hline III.4 & $\mathbf{F}$ & 1958 & 13.5 & $40 \cdot 6$ & 4.66 & 87 & $34 \cdot 0$ & nd & 0.5 & \\
\hline III.5 & $\mathbf{F}$ & 1954 & $\begin{array}{l}12 \cdot 5 \\
11 \cdot 0 \\
\end{array}$ & $\begin{array}{l}38 \cdot 5 \\
34 \cdot 0 \\
\end{array}$ & $\begin{array}{r}5 \cdot 30 \\
4 \cdot 84 \\
\end{array}$ & $\begin{array}{l}72 \\
70 \\
\end{array}$ & $\begin{array}{l}33.0 \\
32.5 \\
\end{array}$ & $\begin{array}{l}1 \cdot 8 \\
1 \cdot 8 \\
\end{array}$ & $\begin{array}{l}3 \cdot 2 \\
3 \cdot 2 \\
\end{array}$ & nd \\
\hline III.6 & $\mathbf{M}$ & 1957 & 13.0 & $37 \cdot 0$ & $4 \cdot 30$ & 88 & 34.5 & $1 \cdot 2$ & $1 \cdot 1$ & \\
\hline III.7 & $\mathbf{M}$ & 1960 & $12 \cdot 4$ & 39.0 & 5.55 & 70 & 32.0 & $\begin{array}{l}2.0 \\
0.6 \\
\end{array}$ & $\begin{array}{r}3 \cdot 5 \\
4 \cdot 0 \\
\end{array}$ & $35: 65$ \\
\hline III.8 & F & 1964 & 11.6 & 35.5 & $5 \cdot 10$ & 69 & 33.0 & $\begin{array}{l}1.3 \\
0.9 \\
\end{array}$ & $\begin{array}{l}4 \cdot 0 \\
3 \cdot 2 \\
\end{array}$ & nd \\
\hline III.9 & F & 1967 & $13 \cdot 4$ & $40 \cdot 0$ & nd & na & 33.5 & 0.8 & 0.8 & \\
\hline
\end{tabular}

The haematological results date from 1971, with the exception of the italicized data which were obtained in 1974 . na = no abnormalitie nd = not done; $s p=$ sporadically present. 
Indonesian, from the middle of Java. The father of I.1 had been born like his ancestors in Arnsberg (near Düsseldorf, Federal Republic of Germany). The results of a haematological and blood group analysis of the family members are presented in Table I. From this analysis and the morphological appearance of the red cells it will be apparent that apart from the abnormal haemoglobin fraction, hereditary elliptocytosis seems also to occur in the family. No aggravation of the anaemia appears to have resulted from the simultaneous presence in II.3, II.5, and II.7 of the abnormal haemoglobin and the elliptocytosis as compared to the abnormal haemoglobin carriers only (I.1, III.1, and III.8). If the conclusion about the presence of an elliptocytosis gene is correct, this gene must have been inherited from the deceased grandmother I.2, who was Indonesian.

Characterization of the abnormal haemoglobin. The abnormal haemoglobin was isolated from the blood of the propositus. The peptide map of the aminoethylated non- $\alpha$ chain showed the presence of the typical $\delta$-chain peptides T2, T3, T5, and $\mathrm{T} 10$ and the typical $\beta$-chain peptides $\mathrm{T} 12 \mathrm{~b}$ and T13; the other peptides are common to both the $\beta$ - and $\delta$-chains. Amino-acid analyses of these peptides showed also the characteristic $\delta$-like composi- tion up to $\mathrm{T} 10$, and a $\beta$-like composition from $\mathrm{T} 12 \mathrm{~b}$ onward (Table II). This proves that the non- $\alpha$ chain is a $\delta \beta$ fusion product in which the crossingover is located between residues 87 in T10 and 116 in $\mathrm{T} 12 \mathrm{~b}$, characteristic of $\mathrm{Hb}$ Lepore Boston.

Since the discovery by Schroeder et al (1968) of the multiplicity of the human $\gamma$-chain genes, considerable attention has been given to the proportion of the two types of $\gamma$-chain, ${ }^{\mathrm{A}} \gamma$ and ${ }^{\mathrm{G}} \gamma$, in different haematological conditions (Huisman et al, 1974). We therefore determined the ${ }^{\mathrm{A}} \gamma:{ }^{\mathrm{G}} \gamma$ ratio in the fetal haemoglobin which is present in low amounts (3$4 \%$ ) in the carriers of $\mathrm{Hb}$ Lepore. This ratio is estimated from the amino-acid analysis of peptide $\gamma \mathrm{CB} 3$, which is the C-terminal fragment of the $\gamma$ chain obtained after treatment with cyanogen bromide. The only difference between ${ }^{A} \gamma$ and ${ }^{\mathrm{G}} \gamma$ is the presence of alanine in position 136 of the ${ }^{\mathrm{A}} \gamma$-chain, where ${ }^{G} \gamma$ has glycine. Careful analysis of the amounts of glycine and alanine in peptide $\gamma \mathrm{CB} 3$ therefore enables the ratio of ${ }^{\mathrm{A}} \gamma$ and ${ }^{\mathrm{G}} \gamma$ in the total $\gamma$-chain pool to be determined. The results are given in Table $\mathrm{I}$.

\section{Discussion}

The haematological findings of heterozygotes for $\mathrm{Hb}$ Lepore Boston and $\beta$-thalassaemia are closely comparable (Weatherall and Clegg, 1972), the only

ANALYSIS AND BLOOD GROUPS OF THE 12 FAMILY MEMBERS STUDIED

\begin{tabular}{|c|c|c|c|c|c|c|c|c|}
\hline \multirow[b]{2}{*}{$\underset{\left(\begin{array}{c}0 \\
0\end{array}\right)}{\mathrm{Hb}}$} & \multirow{2}{*}{$\begin{array}{c}\text { Starch Gel } \\
\text { Electrophoresis }\end{array}$} & \multirow[b]{2}{*}{ Hb Lepore } & \multirow[b]{2}{*}{ Elliptocytosis } & \multicolumn{3}{|c|}{ Red Cell Morphology } & \multicolumn{2}{|c|}{ Blood Groups } \\
\hline & & & & Poikilocytosis & Anisocytosis & $\begin{array}{l}\text { Basophil } \\
\text { Stippling }\end{array}$ & ABO & Rhesus \\
\hline $2 \cdot 5$ & A + Lepore & $7 \cdot 8$ & na & sp & + & + & A & $\mathbf{R}_{1} \mathbf{R}_{2}$ \\
\hline $1 \cdot 9$ & A + Lepore & $9 \cdot 8$ & ++ & $\mathrm{sp}$ & ++ & na & A & $R_{1} \mathbf{r}$ \\
\hline $2 \cdot 8$ & A & & na & na & na & na & A & $\mathbf{R}_{1} \mathbf{r}$ \\
\hline $2 \cdot 2$ & A + Lepore & $9 \cdot 0$ & na & $\mathrm{sp}$ & na & ++ & $\mathrm{O}$ & $\mathbf{R}_{\mathbf{1}} \mathbf{R}_{1}$ \\
\hline $2 \cdot 6$ & A & & na & na & na & na & O & $R_{1} R_{1}$ \\
\hline $2 \cdot 5$ & A & & na & na & na & na & 0 & $R_{1} R_{1}$ \\
\hline $2 \cdot 6$ & A & & na & na & na & na & 0 & $R_{1} R_{1}$ \\
\hline $2 \cdot 7$ & A + Lepore & $10 \cdot 5$ & ++ & + & ++ & na & A & $\mathbf{R}_{1} \mathbf{r}$ \\
\hline $2 \cdot 3$ & A & & + & na & na & na & A & $\mathbf{R}_{1} \mathbf{r}$ \\
\hline $2 \cdot 8$ & A + Lepore & $9 \cdot 0$ & ++ & + & + & + & A & $R_{1} r$ \\
\hline $2 \cdot 9$ & A + Lepore & $9 \cdot 5$ & na & sp & + & \pm & $\mathbf{A}$ & $R_{1} R_{1}$ \\
\hline $2 \cdot 5$ & A & & na & na & + & na & A & $R_{1} \mathbf{r}$ \\
\hline
\end{tabular}


TABLE II

AMINO-ACID ANALYSES OF THOSE TRYPTIC PEPTIDES FROM THE AMINOETHYLATED $\delta \beta$-CHAIN OF Hb LEPORE WHICH HAVE A DIFFERENT COMPOSITION IN THE $\beta$ - AND THE $\delta$-CHAIN

\begin{tabular}{|c|c|c|c|c|c|c|c|c|c|c|c|c|c|c|c|c|c|c|}
\hline \multirow{2}{*}{$\underset{\text { Acid }}{\text { Amino }}$} & \multirow{2}{*}{$\delta \beta T 2$} & \multicolumn{2}{|c|}{ Expected } & \multirow{2}{*}{$8 \beta \mathrm{T} 3$} & \multicolumn{2}{|c|}{ Expected } & \multirow{2}{*}{$\delta \beta T 5$} & \multicolumn{2}{|c|}{ Expected } & \multirow{2}{*}{$\delta \beta \mathrm{T} 10$} & \multicolumn{2}{|c|}{ Expected } & \multirow{2}{*}{$\delta \beta \mathrm{T} 12 \mathrm{~b}$} & \multicolumn{2}{|c|}{ Expected } & \multirow{2}{*}{$\delta \beta T 13$} & \multicolumn{2}{|c|}{ Expected } \\
\hline & & $\delta$ & $\beta$ & & $\delta$ & $\beta$ & & $\delta$ & $\beta$ & & 8 & $\beta$ & & $\delta$ & $\beta$ & & $\delta$ & $B$ \\
\hline Lys & 0.8 & 1 & 1 & & & & 0.9 & 1 & 1 & $1 \cdot 0$ & 1 & 1 & 0.9 & 1 & 1 & 0.9 & 1 & 1 \\
\hline His & & & & & & & & & & 0.9 & 1 & 1 & $2 \cdot 1$ & & 2 & & & \\
\hline Arg & & & & 1.0 & 1 & 1 & & & & & & & & 1 & & & & \\
\hline Asp & 1.0 & 1 & & $2 \cdot 0$ & 2 & 2 & $3 \cdot 3$ & 3 & 3 & 1.0 & 1 & 1 & & 1 & & & & \\
\hline Thr & 0.7 & 1 & 1 & & & & & & 1 & $1 \cdot 2$ & 1 & 2 & & & & $1 \cdot 0$ & 1 & 1 \\
\hline Ser & & & 1 & & & & $3 \cdot 2$ & 3 & 2 & $2 \cdot 0$ & 2 & 1 & & & & & & \\
\hline Glu & & & & $1 \cdot 1$ & 1 & 2 & $1 \cdot 1$ & 1 & 1 & $2 \cdot 3$ & 2 & 1 & & & & $2 \cdot 9$ & 4 & 3 \\
\hline Pro & & & & & & & 1.8 & 2 & 2 & & I & & & & & $1 \cdot 6$ & 1 & 2 \\
\hline Gly & $1 \cdot 1$ & 1 & 1 & $3 \cdot 1$ & 3 & 3 & $2 \cdot 0$ & 2 & 2 & 0.8 & 1 & 1 & $1 \cdot 1$ & 1 & 1 & & & \\
\hline Cys & & & & & & & & & & + & 1 & 1 & & & & & & \\
\hline Val & $1 \cdot 0$ & 1 & 1 & $2 \cdot 8$ & 3 & 3 & 0.8 & 1 & 1 & & & & 0.9 & 1 & 1 & $1 \cdot 1$ & & 1 \\
\hline Met & & & & & & & 0.7 & 1 & 1 & & & & & & & & 1 & \\
\hline Leu & 1.0 & 1 & 1 & 1.0 & 1 & 1 & 0.9 & 1 & 1 & 1.9 & 2 & 2 & 0.9 & 1 & 1 & & & \\
\hline Tyr & & & & & & & & & & & & & & & & 0.7 & 1 & 1 \\
\hline Phe & & & & & & & $3 \cdot 1$ & 3 & 3 & $1 \cdot 0$ & 1 & 1 & $1 \cdot 0$ & 1 & 1 & $1 \cdot 1$ & 1 & 1 \\
\hline Trp & + & 1 & 1 & & & & & & & & & & & & & & & \\
\hline
\end{tabular}

differences being the level of $\mathrm{HbA}_{2}$-normal in $\mathrm{Hb}$ Lepore and increased in $\beta$-thalassaemia-and the presence or absence of the abnormal haemoglobin. The findings in the six carriers of $\mathrm{Hb}$ Lepore in our family are as expected: a mild, more or less wellcompensated microcytic normochromic anaemia; some increase in fetal haemoglobin and in reticulocytes; mild morphological abnormalities of the red cells; mild to marked increase of basophil stippling (in four of our six patients). The amount of the haemoglobin Lepore in the six carriers of our family ranges between 7.8 and $10.5 \%$. Our finding that the ${ }^{\mathrm{a}} \gamma$ chain of the $\mathrm{HbF}$ in our $\mathrm{Hb}$ Lepore carriers makes up between 23 and $39 \%$ of all $\gamma$ chains is in good agreement with the findings of Huisman et al (1972). They found between 27 and $51 \%{ }^{\mathrm{c}} \gamma$ chains in the $\mathrm{HbF}$ of three heterozygotes for $\mathrm{Hb}$ Lepore. Our own findings in two unrelated negroes from Jamaica with $\mathrm{Hb}$ Lepore Boston, who had ${ }^{\mathrm{G}} \gamma$ to ${ }^{A} \gamma$ ratios of $36: 64$ and $28: 72$, respectively, also fall within the same range.

In our six patients there is in addition marked heterogeneity in the morphological appearance of the red cells. Three of the individuals, I.1, III.1, and III.8, are characterized by an increased coarse basophil stippling and some anisocytosis or poikilo- cytosis. The other three have in addition a pronounced ellipto-ovalocytosis, which is much more marked than can be found in thalassaemia. The hypothesis that the difference is caused by the simultaneous presence of a gene for hereditary elliptocytosis in II.3 and his two children, III.5 and III.7, is supported by the finding of ellipto-ovalocytosis only in a further child (III.6), who does not carry the $\mathrm{Hb}$ Lepore. Under this hypothesis the elliptocytosis must have been inherited from I.2 who was Indonesian, born in Java.

Linkage with a Rhesus gene complex might present additional evidence in this respect. Although II. 3 must have inherited the Rhesus $r$ from his mother together with the elliptocytosis, II.2 most likely inherited a Rhesus $R_{1}$ (all his four daughters are $R_{1} R_{1}$ ). The children of II.3 are not very informative because he and his wife both have the genotype $R_{1}$ r. Only III.8 who has the genotype $R_{1} R_{1}$ is informative as a possible non-recombinant, having inherited the $R_{1}$ gene from her father without the elliptocytosis. More definite conclusions about the existence of this elliptocytosis gene cannot therefore be made.

If the presence of an elliptocytosis gene is accepted it is clear from the haematological data that the 
simultaneous presence of $\mathrm{Hb}$ Lepore and elliptocytosis genes does not lead to an aggravation of the anaemia. This combination has not previously been described; combination of elliptocytosis with $\mathrm{Hb} \mathrm{S}$ or Hb C (Wolman and Özge, 1957) and $\mathrm{Hb} \mathrm{E}$ (Lie-Injo Luan Eng, Bolton, and Gilman, 1972) does not produce any haematological symptoms. Association with $\beta$-thalassaemia does seem variably to enhance or not to enhance the thalassaemic symptoms (Aksoy and Erdem, 1968).

It should be emphasized that the different types of Lepore haemoglobins can only be distinguished with certainty by amino-acid analysis of the tryptic peptides $\delta \beta$ T5 and $\delta \beta$ T10. The latter has to be isolated following aminoethylation of the $\delta \beta$-chain. A crossing-over between residues 87 and 116, characteristic of $\mathrm{Hb}$ Lepore Boston, has definitely been shown by Baglioni (1965) in two unrelated individuals of Italian extraction, by Labie et al (1966) in another person of Italian ancestry, and by Baglioni and Ventruto (1968) in a southern Italian. The occurrence of $\mathrm{Hb}$ Lepore Boston in Jamaican negroes has been shown unambiguously by de Jong (1969) and by Ahern et al (1972). Cases of $\mathrm{Hb}$ Lepore Boston from Macedonia and Greece have been characterized by L. F. Bernini (1974, personal communication) and Baglioni and Ventruto (1968).

The geographic origin of the cases of $\mathrm{Hb}$ Lepore from Cyprus (Beaven et al, 1964), Rumania (Rowley, Barnes, and Williams, 1969), and Iran (Rahbar, Golban-Moghadam, and Saoodi, 1974) make it likely that these also belong to the Boston type, although peptide $\delta \beta T 10$ has not been analysed in these instances. The Lepore haemoglobin described by Ranney and Jacobs (1964) in a NorthAmerican negro might just as well be a case of $\mathrm{Hb}$ Lepore Baltimore.

Thus there seem to be two distinct sources of $\mathrm{Hb}$ Lepore Boston: the eastern Mediterranean area extending north into Macedonia and Rumania and east into Iran, and negroes in Jamaica. The finding in our family of $\mathrm{Hb}$ Lepore which must have originated either in Java or in the Federal Republic of Germany might possibly present another source.

We thank Miss A. Gelderblom for expert technical assistance and the members of the family for their cooperation.

\section{REFERENCES}

Ahern, E. J., Ahern, V. N., Aarons, G. H., Jones, R. T., and Brimhall, B (1972). Hemoglobin Lepore WASHINGTON in two Jamaican families: interaction with beta chain variants. Blood, 40, 246-256.
Aksoy, M. and Erdem, S. (1968). Combination of hereditary elliptocytosis and heterozygous beta-thalassaemia: a family study. fournal of Medical Genetics, 5, 298-301.

Baglioni, C. (1962). The fusion of two peptide chains in hemoglobin-Lepore and its interpretation as a genetic deletion. Proceedings of the National Academy of Sciences of the USA, 48, 1880-1886.

Baglioni, C. (1965). Abnormal human hemoglobins: X. A study of hemoglobin Lepore (Boston). Biochimica et Biophysica Acta, 97, 37-46.

Baglioni, C. and Ventruto, V. (1968). Human abnormal hemoglobins: 11 ; A chemical study of hemoglobin Lepore from a homozygote individual. European fournal of Biochemistry, 5, 29-32.

Barnabas, J. and Muller, C. J. (1962). Hemoglobin-Lepore HOLLANDIA. Nature, 194, 931-932.

Beaven, G. H., Gratzer, W. B., Stevens, B. L., Shooter, E. M., Ellis, M. J., White, J. C., and Gillespie, J. E. O'N. (1964). An abnormal haemoglobin (Lepore/Cyprus) resembling haemoglobin-Lepore and its interaction with thalassaemia. British fournal of Haemato$\log y, 10,159-170$.

Bernini, L. F. (1969). A rapid estimation of hemoglobin A2 by DEAE chromatography. Biochemical Genetics, 2, 305-310.

De Jong, W. W. (1969). Characterization of Some Mutants of Human Haemoglobin; Including Two New Variants. Thesis, University of Leiden.

De Jong, W. W. (1971). Chimpanzee foetal haemoglobin; structure and heterogeneity of the $\gamma$ chain. Biochimica et Biophysica Acta, 251, 217-226.

De Jong, W. W., Bernini, L. F., and Meera Khan, P. (1971). Haemoglobin Rampa: $\alpha 95$ Pro $\rightarrow$ Ser. Biochimica et Biophysica Acta, 236, 197-200.

Duma, H., Efremov, G., Sadikario, A., Teodosijev, D., Mladenovski, B., Vlaški, R., and Andreeva, M. (1968). Study of nine families with haemoglobin Lepore. British fournal of Haematology, 15, 161-172.

Fessas, P., Stamatoyannopoulos, G., and Karaklis, A. (1962). Hemoglobin 'Pylos': study of a hemoglobinopathy resembling thalassemia in the heterozygous, homozygous and double heterozygous state. Blood, 19, 1-22.

Huisman, T. H. J., Schroeder, W. A., Bouver, N. G., Miller, A., Shelton, J. R., Shelton, J. B., and Apell, G. (1972). Chemical heterogeneity of fetal hemoglobin in subjects with sickle cell anemia, homozygous $\mathrm{Hb}-\mathrm{C}$ disease, SC-disease, and various combinations of hemoglobin variants. Clinica Chimica Acta, 38, 5-16.

Huisman, T. H. J., Schroeder, W. A., Efremov, G. D., Duma, H., Mladenovski, B., Hyman, G. B., Rachmilewitz, E. A., Bouver, N., Miller, A. Brodie, A., Shelton, R., Shelton, J. B., and Apell, G. (1974). The present status of the heterogeneity of fetal hemoglobin in $\beta$-thalassemia: an attempt to unify some observations in thalassemia and related conditions. Annals of the New York Academy of Sciences, 232, 107-124.

Labie, D., Schroeder, W. A., and Huisman, T. A. J. (1966). The amino asid sequence of the $\delta \beta$-chains of hemoglobin Lepore (Augusta) $=$ Lepore (Washington). Biochemica et Biophysica Acta, 127, 428-437.

Lie-Injo, Luan Eng, Fix, A., Bolton, J. M., and Gilman, K. H (1972). Haemoglobin E-hereditary elliptocytosis in Malayan aborigines. Acta Haematologica, 47, 210-216.

Ostertag, W. and Smith, E. W. (1969). Hemoglobin Lepore BALTIMORE, a third type of $\delta \beta$ crossover $\left(\delta^{50}, \beta^{86}\right)$. European fournal of Biochemistry, 10, 371-376.

Quattrin, N., Bianchi, P., Cimino, R., de Rosa, L., Dini, E., and Ventruto, V. (1967). Study on nine families with haemoglobin Lepore in Campania. Acta Haematologica, 37, 266-275.

Rahbar, S., Golban-Moghadam, N., and Saoodi, H. (1974). Hemoglobin Lepore Boston in two Iranian families. Blood, 43, 1, 7983.

Ranney, H. M. and Jacobs, A. S. (1964). Simultaneous occurrence of haemoglobins $\mathrm{C}$ and Lepore in an Afro-American. Nature, 204, 163-166. 
Rowley, P. T., Barnes, F., and Williams, E. (1969). A Lepore hemoglobin in a Rumanian family. Human Heredity, 19, 48-56.

Schroeder, W. A., Huisman, T. H. J., Shelton, J. R., Shelton, J. B. Kleihauer, E. F., Dozy, A. M., and Robberson, B. (1968). Evidence for multiple structural genes for the $\gamma$ chain of human fetal hemoglobin. Proceedings of the National Academy of Sciences of the USA, 60, 537-544.

Singer, K., Chernoff, A. I., and Singer, L. (1951). Studies on abnormal hemoglobins. I. Their demonstration in sickle cell anemia and other hematological disorders by means of alkali denaturation. Blood, 6, 413-428.

Smithies, O. (1965). Characterization of genetic variants of blood proteins. Vox Sanguinis, 10, 359-362.

Weatherall, D. J. and Clegg, J. B. (1972). The Thalassaemia Syndromes, 2nd edition. Blackwell Scientific, Oxford.

Wolman, I. J. and Ozge, A. (1957). Studies on elliptocytosis: I Hereditary elliptocytosis in the pediatric age period: a review of recent literature. American fournal of the Medical Sciences, 234 702-712. 